\title{
'This is not a pig: Settler innocence and visuality of zoos
}

$>\quad$ Yulia Gilich

Department of Film and Digital Media, University of California Santa Cruz, Santa Cruz, United States of America.

yulia@ucsc.edu (ORCID: https://orcid.org/0000-0002-0641-1041)

\begin{abstract}
Settler innocence is the primary organising principle of Israel's space production. To construct themselves as innocent political actors, oppressors disavow, justify, and deny their responsibility for oppression. The rhetoric of settler innocence allows Israel, a settler colonial state responsible for the dispossession and military occupation of Palestine, to present itself as the "only democracy in the Middle East". In this article, I perform a visual analysis of the Zoological Center Tel Aviv-Ramat Gan and the Jerusalem Biblical Zoo to examine how zoos, inherently violent colonial institutions, reproduce settler innocence. Entrenched in Israel's national projects of linking modernity and Biblical antiquity, zoos naturalise settlers, normalise indigenous displacement, and obscure colonial violence.
\end{abstract}

Keywords: Animal studies, settler colonialism, indigenous theory, visual studies, Israel, Palestine

Published by

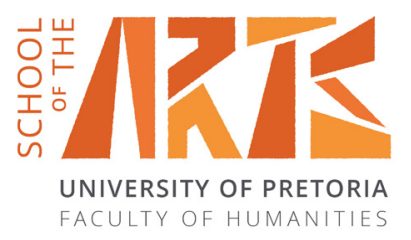




\section{Introduction: The world's worst zoo}

Khan Younis, a zoo in the Gaza Strip, has been dubbed the world's worst zoo. It made headlines when most of its animals died of either starvation or injuries sustained from Israel's air-raids of the Strip. Predicting that he will not be able to smuggle in new animals through the tunnels from Egypt, the zoo's owner, Mohammed Awaida, decided to preserve animal corpses and return them to display, in order to stay in business. Having no experience in taxidermy and no access to quality chemicals, Awaida followed instructions found on the internet to mummify animal bodies. Droopy and patchy, these stuffed animals were placed back in cages, alongside a few surviving animals. In 2016, following an intervention by international animal welfare organisation, Four Paws, Khan Younis was shut down and its animals were transferred to other zoos outside of the Strip. The head of the rescue mission called conditions at Khan Younis 'horrific' and reported that the surviving animals, including a tiger, were happy to leave (Tenorio 2016:[sp]).

As was the case with the media coverage of Khan Younis, Israeli media routinely weaponise the devastating conditions of zoos in Gaza to accuse Palestinians of animal abuse and portray Israel as a benevolent state for helping to rescue the animals.

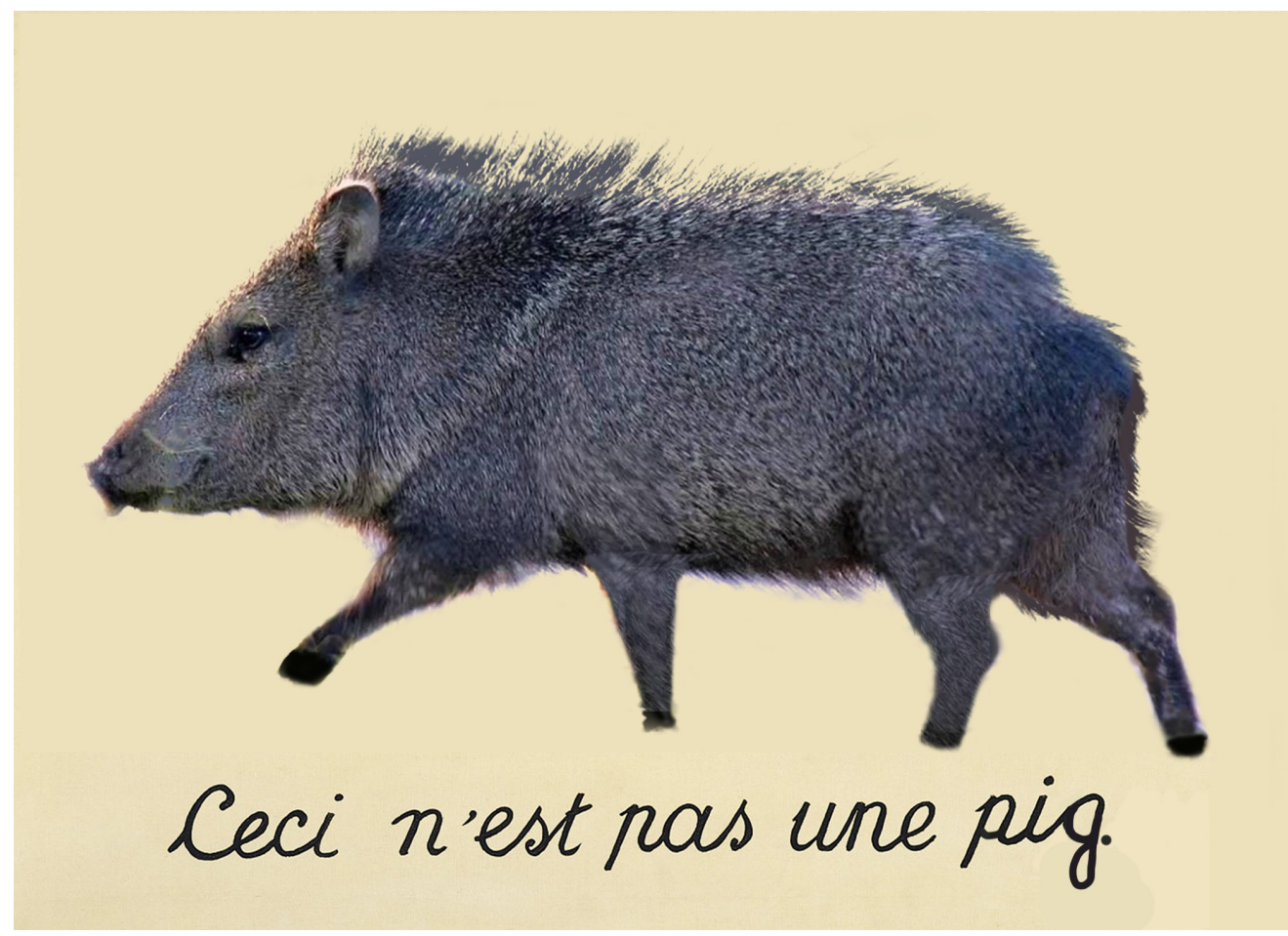

Figure $\mathbf{N}^{\mathbf{0}} \mathbf{1}$

'Ceci n'est pas une pig' (digital collage by Yulia Gilich, courtesy of the author) 
Adding to the chorus is a Jerusalem Post article that contends 'Israel helps evacuate animals as "world's worst zoo" in Gaza closes' (Udasin 2016:[sp]). By presenting zoo animals in Gaza as innocent victims of gratuitous violence inflicted on them by Palestinians, Israel occludes its culpability for having produced the conditions that resulted in the suffering and death of animals. While the humanitarian idea of suffering pretends to universality, the rhetoric of innocence 'parses different kinds of suffering, qualifying them; it provides a moral and cultural frame by which to judge them' (Ticktin 2017:587). Israel's recognition of suffering in the Strip does not extend to the humans of Gaza, who, as Irus Braverman (2017:8) writes, 'it is implied, not only belong there but also deserve such treatment in light of their incivility toward animals'. In Israel's dominant visual regime, Palestinian lives are mediated in such a way that violence against them is invisible, or considered legitimate, or fails to register.

Despite Israeli media often portraying Gaza's animals more favourably than its humans, neither are understood as inherently innocent - a perception supported by the Israeli Defense Minister Avidor Liberman, who in April 2018 proclaimed, 'There are no innocents in Gaza' (Lazaroff 2018:[sp]). Regardless of an animal welfare rhetoric, there is evidence that in each onslaught on Gaza, the Israeli military kills not only hundreds of people but also many of the few animals remaining in the Strip, often deliberately shooting them point-blank (Salih 2014:303). The sniper scope visuality of the Israel Defense Force produces all bodies in Gaza as enemy combatants to justify aggression against them. During military operations, zoo animals are assigned subject positions of Hamas fighters and are presumed to lack innocence because of their existence in that geography (Braverman 2013:150).

The Khan Younis example demonstrates how innocence muddies the human-animal boundary. Humanity and animality are not zoological but political, discursive, and relational designations. Since the period of colonial conquest, animality has been constituted in opposition to 'humanity' and a justification for indigenous genocide. Nicholas Mirzoeff (2016) explicates, '[w]ithin this articulated hierarchy, when people are not considered fully human, they can be occupied, displaced, or even shot without sanction'. Infused with animal traits, racialised and indigenous bodies are denied subjectivity, innocence, and the very right to life. Framed by the white supremacist ideology of race, settler colonial regimes maintain the 'power of humanization' and control over whose lives are rendered grievable, whose lives are made transposable (Byrd 2011), and whose lives are not recognised as lives. The Khan Younis rescue mission thus serves not only to affirm the 'inalienable humanity' (Uddin 2015:34) of Israel, but also to dehumanise Palestinians.

I argue that Israel enrolls zoos in the rhetoric of settler ${ }^{1}$ innocence, which allows the oppressor to systematically deny 'involvement in ... systems of domination' and 'claim 
virtue via oppression' (Mawhinney 1998:17). Eve Tuck and Wayne Yang (2012:10) write that settler moves to innocence are a set of evasions, strategies, and positionings that attempt to rescue settler futurity, reconcile settler complicity, and 'relieve the settler of feelings of guilt or responsibility without giving up land or power or privilege, without having to change much at all'.

In this article, I perform a visual analysis of the Zoological Center Tel Aviv-Ramat Gan (ZCTVRG) and the Jerusalem Biblical Zoo (JBZ), both of which I visited in the summer of 2019. These zoos, produced as modern institutions that contribute to animal welfare and conservation, serve as evidence of Israel's purportedly progressive and democratic nature as a state. Maneesha Deckha (2020:82) reminds us that 'practices towards animals [are marshalled] to assess the civilizational and even human status of different human groups'. Against the backdrop of devastation in Gaza's zoos, Israel's care for animals is meant to validate Israel's innocence and discredit the accusations of inhumane treatment of Palestinians (and Palestinian animals).

\section{The only democracy}

Conceived as fundamentally different from their predecessors, modern zoos claim to be institutions that achieved a 'higher levels of enlightenment' (Uddin 2015:9). No longer in tiny cages behind metal bars, animals in modern zoos inhabit spacious enclosures that recreate their natural habitat. Yet, Stephen Spotte (2006:21) writes that 'zoos have advanced little heuristically since the beginning of the modern age'. Modern zoos never broke away with 'species thinking' (Deckha 2010:38) - a colonial ideology that reifies the exceptionality of 'human' and perpetuates a hierarchy in which certain humans can cage, displace, and display those who are cast as animals.

Modern zoos are descendants of European royal menageries, private collections of exotic animals, and public amusement shows, which included circuses, fairs, and traveling acts exhibiting caged animals and peoples. As early as the 17th century, people from various colonized communities were displayed in Europe alongside nonhuman animals to represent imperial conquest of 'discovered' lands and the 'triumph' of Western colonial powers (Taylor 2017:108). In the 19th century, Carl Hagenbeck, a German merchant who revolutionized zoo displays by getting rid of cages and instead constructing enclosures designed to imitate 'nature', put on fiftyfour ethnographic shows featuring 'exotic' animals and humans from the same regions (Taylor 2017:108). Throughout the 19th and early 20th century, people of African descent were exhibited alongside animals in European zoos and made to impersonate animals in stage show performances (Boisseron 2018:35). Modern zoos, including 
those that renounce the practice of displaying caged people for visitors' amusement, are bound by the legacy of those exhibits. In Israel's zoos, indigenous peoples are no longer a spectacle; rather they are invisibilised and their lands are remade into lush, 'ecologically-accurate' enclosures for the animals. Behind a landscaping idiom of nature and wilderness championed by Hagenbeck, zoos in settler colonial geographies hide the displacement of indigenous people and the infrastructure of violence inherent in any collection of captive animals.

Founded in 1909, Tel Aviv, the pinnacle of Israel's modernity, is imagined to have risen literally out of the sand - an empty land with no prior history, including that of Palestinians. Marking the city's 50th birthday, Tel Aviv's mayor Hain Levanon proclaimed, 'In the beginning there were the sands' (Azaryahu 2006:96). This almost Biblical creation story invokes the notion that Tel Aviv was created ex nihilo - yesh me-ayin (in Hebrew 'something out of nothing'). The sand myth is deployed as evidence of Tel Aviv being built on no-man's land, devoid of previous inhabitants. Representations of indigenous lands as vacant is a central trope of settler invasion that denies any responsibility for indigenous displacement. Israel relies on the Zionist motto that renders Palestine 'a land without a people for a people without a land' (Hochberg 2015:17) to construct settler geographies as innocent. Like the city of Tel Aviv itself, the Zoological Center Tel Aviv-Ramat Gan prides itself on being modern. The zoo occupies approximately 250 acres, which is an equivalent of 189 football fields. The massive animal park - in operation since 1974 - obscures the traces of a Palestinian village, al-Khayriyya, that was depopulated in 1948 by the Jewish pre-state militia, resulting in hundreds of Palestinians having to flee the area (Zochrot [sa]a:[sp]). The innocent geography of settler dwelling and recreation is predicated on the visual erasure of the transposed indigenous bodies.

The defining feature of ZCTARG is the Safari, also called the African Park. It is a sprawling, open range, drive-through area designed to emulate the African savannah. During my visit, as the safari shuttle drove through the immersive landscape, the driver barely slowed down at the sight of African animals in the middle of the Tel Aviv metropolitan area. Nevertheless, I saw a tower of giraffes bending their necks to drink from a lake, a bloat of hippos resting in water, a dazzle of zebras crossing the road in front of us, and an ostrich who for a moment locked eyes with me. To invisibilise animal incarceration, the Safari produces animal sightings as chance encounters as if herds of non-native animals happened to be gallivanting around the pastoral terrain of the colonised Palestinian land sculpted with African characteristics.

One of the visitors who shared the safari shuttle with me, briefly looked at a confusion of wildebeests before announcing with a British accent, 'I would not want to be in 
Africa right now'. Even mistaking a simulation for versimilitude, the visitor perceived her safari adventure as non-threatening compared to being in Africa. According to Rothfels (2002:9), this type of experience is an intended consequence of the zoo design, which allows visitors to unproblematically 'observe exotic animals in their native habitat without leaving the comfort of ... civilization'. The structuring of the gaze in the safari is characterised by what Mary Louise Pratt (1992:169) calls 'imperial eyes' - the visual entitlement of the coloniser who is positioned as 'the monarch of all I survey' (Pratt 1992:169). Designed for white audiences, the 'nature' trope of zoo displays reproduces the colonial sense of mastery and superiority rooted in the power to observe others risk-free.

Another imagery of Africa, that of the gorilla display, is domesticated by positioning the visitors in a wooden cabin elevated above the animal enclosure. Unlike other zoo animals, separated from visitors only by rope or glass, gorillas are additionally removed and thus configured as particularly dangerous. The cabin from which to observe the animals is filled with objects related to travel: suitcases, binoculars, and nature journals. Zoo visitors are constructed as travelers, or rather colonial explorers who have been transported to the gorillas' habitat, which is primarily in central and western Africa. Typical of the colonial gaze that sees 'fully populated spaces as "empty"' (Nelson 2011:162), these animal exhibits neither denote nor allude to African people who are erased from these representations. Unpeopled African landscapes facilitate a historical disavowal: erasure of indigenous people allows the colonisers to 'dissociate from the harmful legacies of colonial power' (Uddin 2015:202) and maintain their innocence.

The tiger enclosure, located in the Asia area, features two elusive Sumatran tigers. Despite the glass display, visitors rarely see the tigers, especially in motion. I spent about 20 minutes near the enclosure and observed most visitors leave not having noticed either of the animals - one asleep on top of a tree and the other, which I only caught a glimpse of, camouflaged in the lush greenery. Next to the enclosure is a colorful display with murals, cartoon-like drawings, objects, and ample wall text, educating the visitors about tigers. One mural illustrates 'four celestial creatures in ancient Chinese mythology' with a drawing of a tiger next to a dragon, phoenix, and tortoise. Another display features a drawing of the actor, Jackie Chan, with a plaque about the 'Tiger and Dragon dojo'. The font used for the wall text in Hebrew, Arabic, and English attempts to imitate Chinese calligraphy: the visual equivalent of imitating a Chinese accent. The entire display, including visual and textual representations of 'Asia', is infused with the 'exotic value' of tigers - endangered animals so rarely seen by humans. While the captive tigers are Sumatran, originating from one of the hundreds of islands that make up Indonesia, the design of the enclosure and its accompanying educational display collapse the continent and concept of Asia into one homogenous 
area, produced as a visual and cultural "other". These representations exoticise the region and reproduce colonial stereotypes that configure Asia as mysterious. The Orientalist imagery also allows Israel to rhetorically construct itself as part of 'the west' despite geographically being located in Asia.

Unlike the visually busy tiger display, the kangaroo enclosure looks bare. There is only a handful of haystacks on the red, arid ground, and a small number of kangaroos are separated from the visitors by a net. What is meant to authenticate the otherwise unassuming display as unmistakably Australian is a drawing of a kangaroo in the style of Australian Aboriginal art on one of the pillars supporting the net. Culturally decontextualised, the simple drawing in this presentation is meant to look primitive - a characteristic that is, in turn, imposed on the Australian Aboriginal people who likely did not author this design.

The promised ecological accuracy of the zoo design mimics animals' natural habitat, while coincidentally reproducing colonial fantasies about non-western geographies the animals are native to. Within modernity's discourses of multicultural inclusion and liberal recognition, these representations serve as evidence of the Zoological Center's claims to be a space of cosmopolitan coexistence of races and species. This selfproclaimed post-racial and posthuman rhetoric 'presupposes that all on the planet is posthuman when, in reality, modernity has reduced the majority of the population to quasi-human' (Mignolo 2018:119). By including ostensibly diverse representations, the framework of modernity obscures mechanisms of racialised violence to reinscribe whiteness as neutral, universal, naturalised, and innocent.

The regime of innocence relies on the discourse of modernity to depoliticise settler colonial power structures and relegate colonial invasion to the ill-defined rhetorical past. It is by tapping into modernity that Israel proclaims itself 'the only democracy in the Middle East' (Cheyfitz 2014:114) and without contradiction renders itself a victim of the conflict it is responsible for. During the 2014 Gaza offensive, ZCTARG widely distributed a video of a herd of elephants gathering to protect their young during an air-raid siren alerting the public of the rockets launched from Gaza. We see a large elephant anxiously swing her trunk and loudly trumpet as if to hurry another elephant walking across the enclosure to join the herd. Four big elephants form a line shielding two calves with their bodies. They all flap their ears and wave their tails as the sound of the siren intensifies. Two elephants tenderly intertwine their trunks; seconds later, the third one joins and wraps her trunk around her mate's tusk. The animals anxiously wait for the danger to pass. Finally, the siren stops. Elephants break the formation and slowly walk across the enclosure, calves proceeding among them. Suddenly, we hear an explosion followed by a scream; the camera shakes but quickly straightens. 
The animals seem unharmed. The camera follows them for a few more seconds until the video fades to black. With its subject confined to the enclosure and unable to run for shelter, the video constructs the rocket attack from Gaza as unprovoked violence seeking to harm innocent actors. The video elicits sympathy for the elephants who rhetorically stand in for Israelis, alerted by the same siren and facing the same enemy. Innocence, as Miriam Ticktin (2017:583) argues, can 'ignore the political and historical circumstances that created these victims' and present perpetrators as victims.

The same political maneuver of using animals as tokens of settler innocence is deployed in the representation of the vulture conservation program at ZCTARG. 'Griffon Vultures need regional peace too' - contends one of the signs. Visitors should infer that Israel is the party that 'too' needs regional peace, as it is engaged in combating the decline in the population of the vultures. Sympathy for the birds should extend to the countries that participate in the conservation programme as suggested by the sign. The vulture sign exhibits a map of the region that demonstrates the vultures' flight trajectory. Imaged without borders, this map of the Middle East and Europe suggests that a borderless existence - the bird's way - is aspirational. However, to demarcate the region, the map names several countries, including those not participating in the vulture conservation program. Yemen, Iran, Eritrea, Sudan, Egypt, Saudi Arabia, Iraq, Jordan, Syria, and Turkey are all typed in a black font; Israel, Greece, Bulgaria, Serbia, and Croatia are designated in white font. While this typographical difference is not explained, it visually groups Israel with overwhelmingly white European countries and separates it from countries with primarily black and brown populations. Palestine is not named on this politically and geographically imprecise representation of the region. Israel visually marks its aspirational belonging to Europe, democracy, and whiteness, which is constructed as politically innocent and virtuous.

The logic of modernity validates zoos as " arks" seeking to conserve animal species' (Philo \& Wilbert 2000:13). Zoos bolster the impression that they rescue endangered animals from the cruelty of nature and global armed conflict while obscuring the reasons why animals become endangered and near-extinct, which is often a result of colonial violence, including hunting, poaching, the capture of animals for zoo exhibits, climate catastrophe, and habitat loss. 'Last chance to see,' says one of the posters promoting nature conservation in the ZCTVGR. The poster features a tiger's face with the animal's eyes looking directly at the camera and, thus, at the zoo visitor. The tiger makes eye contact addressing us directly, pleading to be seen and, by extension, saved from extinction - as if suggesting that the space of the zoo is salvation from the dangers of the world. The modern zoo is presented as being beneficial for animals, which, according to Marjorie Spiegel and Alice Walker (1997:33), is akin to slavery advocates positing that slavery benefited the slaves. Zoo visitors do not see animal 
captivity as bad for the animals - a vision enabled by the same selective colonial optics that allows Jewish Israelis to not see Zionism, Israel's founding ideology, as colonialism, and not recognize themselves as settlers.

\section{Natural order}

Highlighting its conservation mission, the Biblical Zoo in Jerusalem (JBZ), officially known as The Tisch Family Zoological Gardens, takes the ark metaphor literally: the visitor center of the zoo is shaped like an ark. It explicitly points to the Biblical story of Noah saving animals from imminent death in the flood. One of the signs in the zoo dubs Noah as the 'first conservationist in History' and the zoo itself as the 'modern ark'. The kind of conservation the JBZ is concerned with is inextricably linked with Israel's national project. The zoo claims not only to preserve the present but also to 'eternalize the past' (Braverman 2013:129). The JBZ first opened in downtown Jerusalem in 1940 and after several moves ended up in the Malha valley where it has been in operation since 1993. Malha stands on top of a depopulated Palestinian village, alMaliha (Zochrot [sa]b:[sp]), home to thousands of Palestinians prior to 1948 when it was captured by the Israeli military and all inhabitants were displaced.

The JBZ treats the Hebrew Bible (Tanakh) as a historical document at the center of the conservation project. The zoo sees the Israeli state established in 1948 as a direct historical continuation of the Biblical kingdom of Israel from the text dating approximately 3000 years ago. The Zionist national mythology is rooted in the idea that the 'ancient destruction' of the Biblical kingdom was 'righted by the modern rebirth' (El-Haj 1998:169) of the Jewish nation-state. In the zoo, the Biblical text is deployed to strengthen the national narrative that Jewish people in Israel, just as animals in the zoo, have been continuously present in the land for 3000 years and are indigenous to it. The bodies of animals thus serve to bridge the temporal void between the ancient Israelites and their modern Zionist counterparts. This rhetorical connection purportedly proves Jewish indigeneity to Palestine.

The zoo closely follows Biblical commandments as the Bible's text authenticates the animals, plants, and by extension settlers as native. The Bible decrees not only the flora and fauna of the JBZ but also the rules of its daily operations. Braverman (2013: 136) reminds us that 'by its very mission, this is a Biblical Zoo designed to establish the connection of Jews to the Land of Israel'. As per Jewish religious law, Jews are not to work on Shabbat (Saturday), so while the zoo is open on that day, Jews do not work: they do not sell tickets, clean the cages, or feed the animals. People of other religions and ethnicities perform all the paid labour on that day. Braverman 
(2013:136) also remarks that to please its devout Jewish visitors, the zoo changed the language on one of the signs that was interpreted as contradictory to the Bible: '40 million years ago' was changed to 'a long time ago' to prevent further instances of vandalising the sign.

The peccary enclosure is a prime example of how the Biblical commandments overrule other considerations in the design of the JBZ. Though a different species, a peccary looks like a pig, which, according to Jewish religious law, is not allowed to touch Israel's ground. The smelly enclosure with dozens of small, loud animals is surrounded by signs that, in several languages, including Yiddish, inform visitors, 'This is not a pig'. ${ }^{2}$ The signage at the peccary enclosure is the only one in the zoo that addresses the visitors in Yiddish - the language that many ultra-Orthodox Jews who do not read Hebrew use. The surrealist pronouncement, 'This is not a pig', is listed on top of the distinguishing features of the peccary and communicates to the visitors what the animal is not.

In the ark-shaped visitor center, zoo guests can confirm that peccary is not mentioned in the Bible, so according to the Jewish religious law, nothing prohibits it from touching the Israeli ground. There are three computers equipped with software in Hebrew and English designed to locate the Biblical passages that mention plants and animals displayed in the JBZ. One can browse each of the books of the Tanakh, locate an animal on the zoo's map, or search for a specific species in the alphabetical list. The JBZ takes animal taxonomy to heart, just as settler innocence is dependent on the codification of species. A colonial practice established as early as 1735 when Swedish naturalist Linnaeus published his book The System of Nature, taxonomy purports to narrate an 'anti-conquest' (Pratt 1992:28) story of the Empire by just describing 'something that was already there'. In fact, scientific classification, identification, and naming of species are forms of colonial control over nature, knowledge, and indigenous populations, whose expertise of native species is not recognised as long as it does not conform to the taxonomic order.

A software search, along with a careful study of signs throughout the zoo reveal that creative naming and interpretation play an essential role in making connections between individual animals, the Bible, and the national project of Israel. We learn, for example, that 'According to Rabbi Saadia Gaon, the biblical zemer is actually the giraffe'. The JBZ presents an interpretation of the Biblical text by a 10th century rabbi as fact, without questioning it or presenting more evidence, even though the modern Hebrew word for giraffe is girafa and the archaic word is gamal nemer ('leopard camel'). The animal named 'Palestinian gazelle' in English and Arabic signs, is dubbed 'Israeli gazelle' in Hebrew. The sign also posits that the 'Biblical land of Israel is 
called the land of the gazelle'. The erasure of Palestine on the level of language serves to appropriate the literary metaphor in service of the Zionist narrative. The zoo's translation and interpretation practice and its tactical use of Yiddish, as well as the omission of Arabic, produce variations of the Zionist message for different audiences. The Bible is the ideological guarantor of settler innocence and belonging to the land, so the zoo trumps up some of the textual references 'to realize an intrinsically Jewish space, continuously substantiating the land's own identity and purpose as having been and needing to be the Jewish national home' (Braverman 2013:138).

Even though many animals and plants displayed in the JBZ are not mentioned in the Bible, their non-nativeness is made ambiguous through the mixed placement next to the native species and uniform signage across species, regardless of the original habitat. The only animals that are clearly marked as non-native in the zoo are Australian animals. Their enclosures are placed next to each other in an area titled, 'Australian Dreaming'. The wall text elucidates that 'dreaming' is a cosmology of the Australian Aboriginal people that refers to the time of the creation. 'Dreaming' is produced as analogous to the Tanakh that delineates the Jewish cosmology and creation story. The zoo demonstrates an indisputable connection between koalas, kangaroos, wombats, wallabies, and quokkas, the Australian Aboriginal people, and Australian land. Australian Aboriginal people, the only other peoples incorporated in the zoo's narrative, are configured as parallel to Jewish settlers. The zoo is designed to enculturate and discipline the visitors into the view that co-opts the Aboriginal notion of indigeneity to give legitimacy to the settlers' claim to the land of Palestine.

In the Israeli national project, Jewish settlers who recently emigrated from other countries are imagined as having 'returned' to Israel after temporarily being gone, akin to some of the Biblical species that went locally extinct and are now being reintroduced to the land, as per the JBZ's mission. The zoo views the two processes as one and the same in its goal of the 'restoration of the Biblical natural order,' as indicated on a plaque in the zoo. The Zionist ideal of Jewish 'return', embodied by the zoo's Biblical 'restoration', promotes settler innocence by effectively erasing Palestine and its history and curtailing its future.

The most striking example of the JBZ's 'restoration' efforts is the story of the Persian fallow deer. The deer, mentioned in the book of Deuteronomy, could once be found throughout the Middle East but by 1875 remained only in Iran. Using the Islamic Revolution as a perceived threat to the survival of the species, Israel orchestrated a military operation to "rescue" the deer. In the name of conservation, Mossad, Israel's intelligence agency, smuggled the critically endangered animal from Iran. ${ }^{3}$ 
Today, the JBZ holds the largest captive herd of Persian fallow deer in the world. Deer were bred in captivity so that they can be 'reintroduced' into their once native habitat - the Jerusalem hills. However, the zoo admits that the project had limited success. Over $60 \%$ of deer released around Jerusalem have died from train accidents, a fact that articulates the violent disjunction between the Biblical past of the Kingdom of Israel and the industrialised modernity of the Israeli nation-state. Still, the fallow deer project is the JBZ's proudest achievement in its 'global mission to save endangered species and their ecosystems' (Braverman 2013:129).

The sign promoting the deer and onyx's 'return ... to their natural environment' features a drawing of a deer pointing to the river and the hills - as if motioning other animals to join her on the journey, almost like in the Biblical story of Moses leading the Jewish people on their journey from enslavement in Egypt to freedom in the land of Israel. The deer and onyx enclosure overlooks the Jerusalem hills (where the animals are being 'reintroduced'), which loosely repeat the contours of the landscape in the drawing. Behind the animal enclosure are not only the hills, but also the West Bank and the Apartheid Wall that separates East and West Jerusalem. My experience of looking at the landscape was analogous to the premise of Antonioni's cult classic Blowup. With the naked eye, I could not see the Wall - the violence it inflicts on the Palestinian people is obscured, and the view is presented as peaceful. Once I zoomed in with the camera, not only did the Wall become visible, but also the checkpoint, the soldiers manning it, and the structure of oppression that keeps Palestine out of sight. That's what the JBZ and, broader, the national project of Israel is about - a quintessential view that seems peaceful while, in reality, is obscuring the violence of colonial space-making to protect settler innocence.

\section{Conclusion: 'Why look at animals?'}

In Israel, like in other settler colonial geographies, zoos reproduce settler spatial entitlement - the right to claim, displace, and possess. As 'microcosms of empire' (Hanson 2018:8), zoos rely on seeing the world, including non-settler lives and modes of being, as objects of possession. Zoos' authentic mission - making animals properly visible - celebrates the imperial eye, and the right of the coloniser to see, or indeed to stare. Our visual pleasure justifies animal captivity and promotes the idea that 'the captured rhinoceroses will far more "benefit the world" than forty adults "running wild in the jungles ... seen only at rare intervals by a few ignorant natives"' (Rothfels 2002:248). This rhetoric normalises animal removal from their native habitats and their entrapment on dispossessed indigenous lands. 
All zoos are places of animal captivity that reduce animals to spectacles. Animals are 'emptied of experience and secrets' (Berger 2009:12), so that visitors can project themselves onto the animals and see themselves reflected back. Berger (2009:23) writes that we look at zoo animals in the 'hope of re-finding some of the innocence' we believe animals to possess. This observation is applicable to modern zoos, including those in Israel. Animal displays in the Zoological Center Tel Aviv-Ramat Gan and the Jerusalem Biblical Zoo reflect and reaffirm settler innocence, and take settler minds off occupation. Gaza's zoos, in turn, are not innocent. They are highly politicised they don't erase the violent infrastructure of animal captivity from the zoo design and instead call attention to the occupation. The aesthetics of Gaza's zoos reflect the material conditions of Gaza's humans. They see themselves in their animals - starved and traumatised. Animal corpses testify to lives lost in the conflict, implicate the occupiers responsible for it, and point to the siege as creating unlivable conditions in the Strip.

\section{Notes}

1. By settlers I mean here not only dwellers of illegal settlements in the Occupied Palestinian Territories, but all non-Palestinian citizens and residents of Israel-a settler colony founded in Palestine in 1948.

2. Inadvertently, the phrasing of the sign alludes to René Magritte's surrealist painting, This is Not a Pipe.

3. I expected this operation to be classified and was ready to try to liberate records about it through Israel's and Iran's Freedom of Information laws. However, a quick search revealed the operation is not a state secret. Quite the opposite - its story is told with pride in the media (Levison 2010).

\section{References}

Azaryahu, M. 2006. Tel Aviv: Mythography of a city. Syracuse, N.Y: Syracuse University Press.

Berger, J. 2009. Why look at animals?. London, New York \& Toronto: Penguin Books.

Boisseron, B. 2018. Afro-Dog: Blackness and the animal question. New York: Columbia University Press.

Braverman, I. 2013. Animal frontiers: A tale of three zoos in Israel/Palestine. Cultural Critique 85:122-162.

Braverman, I. 2017. Captive: Zoometric operations in Gaza. Public Culture 29(1):191-215.

Byrd, J. 2011. The transit of empire: Indigenous critiques of colonialism. Minneapolis: University of Minnesota Press.

Cheyfitz, E. 2014. The force of exceptionalist narratives in the Israeli-Palestinian conflict. 
Deckha, M. 2020. Unsettling anthropocentric legal systems: Reconciliation, indigenous laws, and animal personhood. Journal of Intercultural Studies 41(1):77-97.

Deckha, M. 2010. The subhuman as a cultural agent of violence. Critical Animal Studies 8(3):28-52.

El-Haj, N. 1998. Translating truths: Nationalism, the practice of archaeology, and the remaking of past and present in contemporary Jerusalem. American Ethnologist 25(2):166-188.

Hanson, E. 2018. Animal attractions: Nature on display in American zoos. Princeton: Princeton University Press.

Hochberg, G. 2015. Visual occupations: Violence and visibility in a conflict zone. Durham: Duke University Press.

Lazaroff, T. 2018. 'There are no innocents in Gaza,' says Israeli Defense Minister. The Jerusalem Post. Available:

https://www.jpost.com/Arab-Israeli-Conflict/There-are-no-innocents-in-Gazasays-Israeli-defense-minister-549173.

Accessed 19 April 2020.

Levinson, C. 2010. How Bambi met James Bond to save Israel's 'extinct' deer. Wall Street Journal. Available:

https://www.wsj.com/articles/SB10001424052748703389004575033010944848670. Accessed 19 April 2020.

Mawhinney, J. 1998. 'Giving up the ghost': Disrupting the (re)production of white privilege in anti-racist pedagogy and organizational change. Available: https://www.collectionscanada.gc.ca/obj/s4/f2/dsk2/tape15/PQDD_0008/ MQ33991.pdf. Accessed 9 October 2020.

Mignolo, W. 2018. On decoloniality: Concepts, analytics, and praxis. Durham: Duke University Press.

Mirzoeff, N. 2016. How to see Palestine: The example of Palestine. Available: http://scalar.usc.edu/nehvectors/how-to-see-palestine/the-example-ofpalestine-every-day. Accessed 12 April 2018.

Nelson, R. 2011. Emptiness in the colonial gaze: Labor, property, and nature. International Labor and Working-Class History 79:161-74. 
Philo, C \& Wilbert, C. 2000. Animal spaces, beastly places: New geographies of humananimal relations. London: Routledge.

Pratt, M. 1992. Imperial eyes: Travel writing and transculturation. London: Taylor \& Francis.

Rothfels, N. 2002. Savages and beasts: The birth of the modern zoo. Baltimore: Johns Hopkins University Press.

Salih, S. 2014. The animal you see: Why look at animals in Gaza? Interventions 16(3):299324.

Spiegel, M \& Walker, A. 1997. The dreaded comparison: Human and animal slavery. New York: Mirror Books/IDEA.

Spotte, S. 2006. Zoos in postmodernism: Signs and simulation. Madison: Fairleigh Dickinson University Press.

Taylor, S. 2017. Beasts of burden: Animal and disability liberation. Illustrated edition. New York: The New Press.

Tenorio, R. 2016. Animal rescue operation complete as 'World's worst zoo' closes in Gaza. Times of Israel. Available: http://www.timesofisrael.com/animal-rescue-operation-complete-as-worldsworst-zoo-closes-in-khan-younis/.

Accessed 19 April 2020.

Ticktin, M. 2017. A world without innocence. American Ethnologist 44(4):577-90.

Tuck, E \& Yang, W. 2012. Decolonization is not a metaphor. Decolonization: Indigeneity, Education \& Society 1(1):1-40.

Udasin, S. 2016. Israel helps evacuate animals as 'world's worst zoo' in Gaza closes. The Jerusalem Post. Available: https://www.jpost.com/middle-east/israel-help-evacuate-animals-as-worldsworst-zoo-in-gaza-closes-465902.

Accessed 10 December 2020.

Uddin, L. 2015. Zoo renewal: White flight and the animal ghetto. Minneapolis: University of Minnesota Press.

Zochrot. [sa]. al-Khayriyya. Available: https://www.zochrot.org/en/village/49173. Accessed 9 October 2020.

Zochrot. [sa]. al-Maliha. Available: https://www.zochrot.org/en/village/49251. Accessed 9 October 2020. 